\title{
O QUE VEM A SER O INDIVÍDUO EGOLATRA?
}

\author{
Hilton Japiassu* \\ (in memoriam)
}

No fundo, o homem perdeu a fé em seu valor
Nietzsche

Camus

As paixões que consomem se consomem velozmente

E. Morin

Em nossas sociedades ocidentais de hoje, encontramo-nos em presença de um indivíduo podendo ser caracterizado de hipermoderno, posmoderno ou, simplesmente, egolatra (do lat. Ego: eu e do gr. latria: culto, adoração), radicalmente distinto do indivíduo da "era moderna", pois está muito mais preocupado com o amor

\footnotetext{
* Texto in memoriam foi enviado por Japiassu para ser trabalhado no III Seminários Analíticos de Temas Interdisciplinar - SATI com o tema "Diálogo Transdisciplinar: possibilidades e limites", que ocorreu em 22 de junho de 2013. Após o feliz encontro com esse poeta da interdisciplinaridade, a editora chefe da Revista de Pesquisa Interdisciplinar vem solicitar à sua sobrinha Danuzia algumas palavras para a tardia, mas valora publicação para todos que o conheceram e que desejam conhecer nosso grande amigo e intelectual brasileiro. Ao receber o convite para tecer algumas palavras sobre o amado tio, deixa transparecer a herança intelectual e afetiva nas seguintes palavras:

"Confesso que o seu contato me permitiu reviver, rememorar e sentir um misto de alegria e dor. Ao mesmo tempo, reafirmar alguns compromissos assumidos com o tio Hilton. Confesso que também chorei, mas também sorri...enfim!! como ele adorava dizer repetidas vezes: enfim!! Aqui estou com um pouquinho do muito que ele me deixou.

O privilégio de ter Japiassu como interlocutor vivo, doce, sereno e generoso, expressou o que hoje tenho como um de seus legados na minha vida pessoal e profissional. Assim, com ele, junto dele e para além dele, foi sábio o suficiente em não me apresentar respostas prontas e acabadas. Não abriu portas que me permitissem sair do labirinto que eu mesma havia construído. Não foi intransigente ou arrogante, mas humilde o suficiente para dizer de forma competente e singela:

"Se quiseres exercer alguma influência no rumo empreendido pela ciência contemporânea, é preciso que tomemos consciência da necessidade de uma ampla ação: uma ação direta tentando dominar os conhecimentos científicos e detectar suas ilusões; uma ação indireta, convertendo-nos em pedagogos capazes de formar aqueles que mudarão o mundo. Para tanto, temos que nos transformar por dentro e, ao mesmo tempo, criar as condições exteriores, tornando possível uma transformação no mundo do saber. Este tipo de atividade constitui uma ruptura no encadeamento do determinismo histórico cego e merece denominação: fazer a história".

É...

Tem dia que a saudade dói com mais intensidade. Tem dia que a ausência pesa. Tem dia que o silêncio incomoda. Tem dia que se estende para a noite e a falta faz profunda falta. Japi, tio Hilton, amigo e eterno professor, interlocutor de um diálogo marcado pela dor da sua ausência. Sigo, mas declaro: que falta você me faz." (DANUZIA, 2 de março de 2017).
} 
exclusivo de si, em satisfazer a todo custo seus interesses pessoais e fazer de si um efetivo objeto de culto. Quer se mostre autônomo, reflexivo, em pane, incerto ou narcísico, o fato é que se encontra no centro das atuais interrogações de nossa sociedade. A partir da segunda metade do século passado, profundas mutações econômicas, científicas, tecnológicas, culturais, sociais, religiosas e éticas conduziram à emergência de um novo indivíduo, cujo modo de ser, pensar, fazer, viver, sentir e agir difere profundamente da maneira de ser de seus predecessores. As várias descobertas científicas, o desmoronamento das ideologias de esquerda, a globalização da economia, o triunfo da sociedade de consumo e a flexibilidade generalizada (produzindo novas exigências de performance e criatividade), juntamente com a revolução ocorrida nas tecnologias da comunicação desempenharam um papel fundamental no advento desse novo indivíduo. O triunfo da lógica mercantil e a explosão de todos os limites que até então estruturavam as identidades individuais contribuíram de modo decisivo para se definir o que ele se tornou, moldando sua identidade, seus sentimentos, seu modo de ser, agir e pensar.

Não vai nos interessar tanto saber se esse indivíduo livre e dotado de direitos (nascido no século XVII), continua ainda livre ou se é definido pelas estruturas sociais. Sabemos que sua autonomização crescente não significa menos sociedade, pois constitui uma forma de organização coletiva. Não somos forçados a escolher entre o indivíduo e a sociedade. Estas realidades nos são dadas ao mesmo tempo com o paradoxo que lhes vem associado: o indivíduo é plenamente social e a sociedade é a resultante das ações individuais. O indivíduo é o lugar onde se articulam o ator e o sistema, a ação e os fatos sociais, a subjetividade e a objetividade, a construção da sociedade e sua imposição aos atores. Ele se afirma como um sujeito autônomo e independente, apegado à sua própria identidade pela consciência ou o conhecimento de si. Quando Aristóteles definiu o homem como um zoôn politikôn, estava enfatizando ser ele um ser, por essência, coletivo e político. Bem mais tarde, Marx iria reconhecer que não devemos considerar a sociedade como uma abstração em face do indivíduo, pois este se define essencialmente como "ser social". Embora saibamos que muitos de nós nem sempre dispomos dos recursos requeridos para sermos e permanecermos "indivíduos de facto". Por outro lado, não é absolutamente seguro que existam realmente soluções individuais para problemas socialmente construídos. O sociólogo Bourdieu e o filósofo-psicanalista Castoriadis não se cansaram de nos advertir que só há uma chance de resolvermos os problemas gerados socialmente: a solução coletiva. Em 
nossas sociedades atuais, o indivíduo vive mais ou menos entregue a si mesmo. É convidado a desempenhar o papel de ator devendo escolher de modo autônomo. E representar a figura do homo eligens ("ator que escolhe"). Como se essa figura constituísse objeto de escolha!

Vivendo numa sociedade que se funda nos seguintes postulados: a) a economia é um domínio à parte governado por leis naturais e universais devendo ser cegamente obedecidas; b) o mercado é o melhor e o único meio de organizar a produção e as trocas de modo eficaz e equitativo: c) a globalização exige a redução das despesas estatais, especialmente no domínio dos direitos sociais e de segurança, tidos por custosos e disfuncionais, esse novo indivíduo (hiper- ou posmoderno) pode ser caracterizado por sua capacidade de viver em excesso os valores de nossa atual cética, cínica e niilista sociedade de consumo hedonista. Nesta sociedade, o sujeito cidadão de direitos se converte num indivíduo buscando desesperadamente afirmar-se no espaço social como alguém capaz de ter ou conquistar e de ser reconhecido. Ao abandonar as estruturas de solidariedade coletiva, afirma-se na disputa ferrenha e competitiva por um lugar ao sol no mundo social midiatizado. Em praticamente todos os domínios (econômico, político, social, etc.), acredita desempenhar um papel fundamental, pois constituiria a verdadeira realidade e o fundamento dos valores. Donde a ideologia individualista que, segundo Nietzsche, nada mais é que "uma variedade modesta e ainda inconsciente da vontade de poder", pois o indivíduo "se contenta em se libertar da dominação da sociedade (do Estado ou da Igreja)" como se pudesse subordinar a seus caprichos a totalidade social.

Com o recuo do Estado, com a privatização acelerada da religião e da família, impõe-se como uma espécie de absoluto o mercado, anunciando um novo culto: o da concorrência econômica e democrática, alimentado pela ambição tecnocientífica e pela defesa intransigente dos "sagrados" direitos do indivíduo. Porque esta sociedade desregulamentada e globalizada, absolutamente moderna ou hiper-moderna deve fundar-se em três artigos de fé: no mercado, na eficácia técnica e no indivíduo. Com o enfraquecimento dos sistemas de proteção estatal às intempéries da vida, passa a viver num ambiente de profunda incerteza e a se considerar responsável pelos eventuais fracassos individuais. E com o desaparecimento da perspectiva de planejamento a médio e a longo prazos, e com o divórcio entre poder e política, fica condenado a viver no aqui e no agora. Sem esperança ou utopia, o presente passa a ser insuportável. Donde seu refúgio nas drogas, nos misticismos ou em outros tranqüilizantes ao alcance da mão. Não estaria condenado a viver no tédio ou na depressão? A frustração de seus desejos 
ou a inquietude que não conseguiu tranqüilizar levam-no a esperar estados "extáticos" impondo-se como a libertação de uma ausência. As alegrias e o bem-estar imaginários que ele espera obter transformam-se em figuras invertidas de seus sofrimentos. Mas se sua existência é dolorosa, parece-lhe preferível à ausência de desejo, sintoma de uma melancólica apatia. Sem o desejo e seu cortejo de sofrimentos, o indivíduo só experimenta a vacuidade de uma experiência desprovida de objetivo.

Ora, vivendo numa sociedade onde não mais consegue encontrar sentido para as coisas materiais, em geral, e para sua vida pessoal, em especial, pois teria perdido toda consistência e toda importância; ademais, vivendo numa sociedade que se arma da insegurança ao mesmo tempo que exalta o individualismo e a self help, e se afirmando como a encarnação de uma visão neo-darwinista cuja mentalidade é calculadora, impregnando toda a vida e todos os domínios da prática, inclusive as instituições ("academic market place") e as trocas cotidianas, claro que esse indivíduo posmoderno, fazendo do culto do "individualismo" o fundamento mesmo do pensamento econômico, tornou-se um dos pilares da "ideologia" ou "opinião corrente" segundo a qual vêm se constituindo e se apresentando as ciências sociais. Por exemplo, a chamada "ciência econômica" repousa sobre uma filosofia da ação marcada pelo individualismo metodológico não podendo nem pretendendo conhecer outra coisa senão as ações sabidamente calculadas de agentes individuais e visando fins estritamente egoístas conscientemente estabelecidos.

Não nos esqueçamos de que os valores constituem uma condição que, ao ser eliminada, torna a vida absurda.. Tampouco que o pragmatismo americano proclama (Declaração da independência), não a felicidade para todos, mas o direito, para cada um, de "buscar sua felicidade" em função de seus desejos e de seus meios. Quanto às ações coletivas ou de solidariedade, ficam reduzidas a simples agregações de ações individuais isoladas. De fato, elas excluem a política, pois a reduzem a um simples somatório de atos individuais que, uma vez realizados (como o voto) no isolamento e no segredo, constituem o exato equivalente do ato solitário de compra num supermercado. No dizer de Bourdieu "a filosofia da economia e da relação entre a economia e a política é uma visão política que conduz a instaurar uma fronteira intransponível entre o econômico regido pelos mecanismos fluidos e eficientes do mercado, e o social, habitado pelo arbitrário imprevisível da tradição, do poder e das paixões" (Op. cit.,p.29). 
Na mesma época da declaração de independência americana, o filósofo Kant, pressentindo os riscos que corria um Estado que pretendesse dar-se por missão garantir a felicidade de seus membros, contra sua vontade, escreve: "O soberano que pretende tornar o povo feliz segundo a idéia que se faz da felicidade, torna-se déspota; mas o povo que não deseja deixar-se frustrar da pretensão à felicidade comum a todos os homens, torna-se rebelde". Esta situação ainda parece atual. Os regimes totalitários do século XX (notadamente nazismo e stalinismo) nos mostraram o quanto foi perigoso confiar ao Estado o cuidado de assumir a responsabilidade pela felicidade individual. Foi um fracasso geral. Neste domínio, saiu vencedora e reforçada a autonomia individual. Compete ao Estado apenas afastar os obstáculos que se interpõem e barram a felicidade dos indivíduos, não garanti-la. Não deve ser portador de esperanças, apenas prestador de serviços.

Nas sociedades mais avançadas, a prosperidade, o fim das ilusões revolucionárias e a ascensão do neoliberalismo econômico e do liberalismo moral levaram o indivíduo contemporâneo a um grau de narcisismo bastante profundo. Ademais, ao anular os valores ligados à Transcendência, passa a viver na perda de todos os ideais. Tomado entre a ausência de ideal e o fascínio pelo prazer, este indivíduo só se preocupa com sua felicidade privada. Como se a felicidade consistisse em poder desfrutar do maior número possível de bens materiais! Mesmo aí, o medo de se decepcionar e a recusa das coerções excluem toda forma de engajamento durável. Ao evocar certo renascimento das práticas religiosas, Lipovetsky enfatiza até que ponto elas diferem daquilo que poderia ser uma adesão pessoal mais profunda: "a atração religiosa não passa de enfeitiçamentos efêmeros, embora poderosos para esta ou aquela técnica relacional, dietética ou esportiva". Mesmo nestas matérias consideradas sérias, não há continuidade: tudo é moda, mudança, leviandade. Pode isto ser considerado um progresso ou uma decadência? Uma forma de emancipação ou o sinal de uma decomposição? $\mathrm{O}$ que não podemos admitir é que ocultemos o desmoronamento niilista dos grandes valores com as imagens do interesse individualista e do hedonismo. Porque sabemos que é a atomização dos indivíduos que provoca sua inevitável solidão, por conseguinte, que o leva a viver num nefasto egoísmo niilista. E. Morin o alerta para um possível naufrágio se deixar-se atrair pelos cantos da sereia ou pelas sirenes do irracional: 
"As paixões que consomem se consomem velozmente; o amor se enfraquece multiplicando-se e, com o tempo, torna-se frágil. Os encontros que fazem nascer um novo amor matam o antigo. Os casais se desfazem, outros se formam e novamente se afastam. No amor entra o mal da instabilidade, da pressa e da superficialidade, que reintroduz o mal da civilização esmagado pelo amor" (TERREPATRIE, 1993, p. 84).

O fato é que estamos vivenciando hoje um certo naufrágio e assistindo ao aparecimento de novas ilusões. O naufrágio é o do indivíduo que se tornou demasiado "narcísico", flutuando, emocionalmente vazio, acossado pela depressão e por todos os tipos de distúrbios da motivação. Seu consumo desregrado se torna hiperconsumo bulímico alternando-se com dietas de privações: a obsessão dietética e pela boa forma multiplica os medos narcisistas e os caprichos alimentares. Nos ricos, o consumo se torna histérico, maníaco pelo standing, pela beleza, pela saúde, pela auto-estima, etc. A tal ponto que a mania das frivolidades se transforma em mania das futilidades. $O$ preço a ser pago? A transformação do trabalho, de meio, em fim. Nietzsche já havia previsto o mecanismo perverso desse tipo de histeria: "É preciso trabalhar, senão por gosto, pelo menos por desespero, porque, feitas as contas, trabalhar é menos tedioso do que se divertir".As novas ilusões são as da liberdade: por detrás do prazer de consumir e das facilidades comunicacionais se esconde, de fato, a mão de uma gestão tecnocrática dos comportamentos voltada para um ideal de "regulação total e microscópica do social". As perdas (de sentido) e as ausências (de idéias, de ação. de paz real) podem conduzir os indivíduos à idéia de uma "era do vazio" psíquico, por conseguinte, do desespero. Donde o recurso à toxicomania, onde se põe em jogo a noção mesma de autonomia: o toxicômano é um culpado ao mesmo tempo que um doente sofrendo de um "distúrbio de identidade". Acabrunhado pelo medo do fracasso e pelas flutuações constantes de seu desejo, vive na depressão, nesta doença da responsabilidade que revela seu êxito no momento em que o modelo disciplinar das gestões das condutas, as regras de autoridade e de conformidade aos interditos cederam diante das normas que incitam cada um à iniciativa individual. A depressão é o distúrbio mental mais difundido no mundo, apresentando-se como a mais específica patologia da liberdade, como o grande "mal da civilização" cuja natureza é assim descrita por E. Morin e Anne B. Kern:

É muito difícil reconhecermos a verdadeira natureza do mal da civilização, dadas todas suas ambivalências e complexidades. Precisamos ver seus subsolos minados, as cavernas e os abismos subterrâneos, bem como o desejo de viver e a luta inconsciente contra

RPI Revista de Pesquisa Interdisciplinar, Cajazeiras, v. 1, n. 1, 91-110, jan/jul. de 2017. 
o mal. Precisamos ver o conjunto de desumanização e de reumanização. Precisamos ver as satisfações, os sofrimentos, as frustrações, as angústias e as infelicidades do mundo desenvolvido. Quem luta contra as forças de morte dessa civilização, também faz parte dela. As neuroses que provoca não constituem apenas um efeito do mal, mas um doloroso compromisso com ele para por ele não ser devorado (...) Após ter liberado incríveis forças criativas e desencadeado inacreditáveis forças destrutivas, nossa civilização se encaminha para sua autodestruição ou para sua metamorfose (TERREPATRIE, 1993, p.85).

Tornando-se cada vez mais responsável pela duração e pela qualidade de sua vida, o indivíduo contemporâneo sabe que pode desempenhar um importante papel no desencadeamento das patologias, pois numerosas doenças (cânceres e doenças cardiovasculares) dependem do fumo e do álcool, da alimentação e do exercício físico. Tendose tornando uma espécie de médico de si mesmo, ele escolhe ou recusa a morte precoce e a saúde. Vivemos hoje na era da "tanatotécnica" (M. Serres). A ponto de o indivíduo apresentar facetas bastante contraditórias: centrado na satisfação imediata de seus desejos e intolerante em relação às frustrações, persegue novas formas de ultrapassamento de si e, numa busca de absoluto, sempre se agarra ao que mostra ares de atualidade e novidade. Sobrecarregado de solicitações de posse e de apelos a emoções, convidado a ser sempre mais performante no plano da ação e obcecado pela urgência, desenvolve comportamentos compulsivos visando aproveitar cada instante num máximo de intensidade possível, mas correndo o risco de cair num "excesso de inexistência" quando a sociedade dele retira os suportes indispensáveis para fazer dele um indivíduo plenamente realizado no plano do ser. O velho Sócrates já nos mostrou: não é verdade que é feliz quem vive afogado no aqui e agora, buscando satisfazer todos os seus desejos, devorando tudo e procurando ter cada vez mais: "Não é verdade que são felizes os que não precisam de nada"!

O indivíduo atual passa por uma verdadeira mutação antropológica: em relação a seu corpo, ao tempo, aos outros, a si mesmo e à transcendência. Nosso corpo deixa de estar submetido à tirania da doença, da dor e da maternidade, embora freqüentemente seja reduzido, não só a um "instrumento vivo de consumo", mas também de "produção", escravo de uma cultura tecnocientífica, engrenagem de um sistema cuja lógica lhe escapa. Quanto à nossa relação com o tempo, constitui o objeto de uma aceleração contínua. Passamos de um período em que éramos submetidos ao tempo a outro onde não cessamos de violentá-lo para dele retirarmos o máximo de 
proveito e prazer possíveis. O tempo do indivíduo moderno era ritmado pelas obrigações da vida social e do trabalho. $\mathrm{O}$ indivíduo atual pretende dominar o tempo, ser seu mestre. Na lógica capitalista, "tempo é dinheiro", lógica essa devendo ser traduzida por uma aceleração cada vez maior. Claro que essa pulsão de dominar o tempo possui um suporte econômico, pois a competição se deslocou para o campo do tempo, com sua ditadura real sustentando a economia: é ganhando tempo que se conquista os mercados. Mas a radicalização dessa lógica de aceleração é feita hoje pela generalização do reino da urgência, o máximo de coisas devendo ser feitas num mínimo de tempo. Trata-se de uma urgência que remete a um "tempo social rarefeito" que nos impulsiona a agir cada vez mais depressa para levarmos vantagem em nossos empreendimentos. O que nos leva a viver uma espécie de ubiqüidade existencial, tendo a impressão de podermos estar em toda parte ao mesmo tempo, nem que seja pelo celular ou pelo computador. Embora o indivíduo tenha a ilusão de dominar o tempo, é por ele tiranizado pela urgência, notadamente na vida profissional e, finalmente, prisioneiro do tempo que tentou dominar.

E o que dizermos das relações do indivíduo com os outros? Diria que se tornam cada vez mais flexíveis e efêmeras. No mundo de hoje, muitos preferem buscar, não o ser, mas o aparecer, a aparência (o look). Não importa o que você é, mas o que você tem, o que os outros pensam que você é ou tem. As novas tecnologias da comunicação nos forçam a valorizar a instantaneidade dessas relações. A tal ponto que podemos dizer: "existo na medida em que estou conectado". A gente se torna incapaz de se representar de outra forma senão "em relação com". Tudo se passa como se adotássemos a filosofia individualista (de tipo estóico) privilegiando a propriedade de si, o ideal da humanidade sendo o de se possuir: tornar-se o mestre de sua relação com o exterior. Desta ética de si decorrem a capacidade de solidão, a valorização do imaginário e das atividades intelectuais. É a autonomia do sujeito de razão, embora nossa existência subjetiva permaneça dependente do exterior, subordinada à relação com os outros. Mas os outros, não seriam o inferno? Ao dizer que "o inferno são os outros", Sartre não está fazendo deles os responsáveis por nossas desgraças. Sua filosofia afirma o contrário: nada nos permite acusá-los daquilo que vivemos: somos livres para fazer nossas escolhas. Por mais absurda que pareça nossa vida, precisamos “imaginar Sísifo feliz”, nos diz Camus. Porque sua vitória é absurda, é a felicidade do desespero. Ora, "não existe punição mais terrível que o trabalho inútil e sem esperança".

RPI Revista de Pesquisa Interdisciplinar, Cajazeiras, v. 1, n. 1, 91-110, jan/jul. de 2017. 
Mas como essa tomada de consciência é difícil e angustiante, procuramos um meio de nos desembaraçar do peso da culpabilidade. Como no universo existencialista de Sartre Deus não existe, é o olhar do outro que nos julga, pois o outro é "este eu que não sou eu". Sendo assim, o inferno são os outros, não porque nos desejam o mal, mas porque encarnam a mais implacável das condenações remetendo-nos a nós mesmos. Goethe tinha razão ao declarar: "Para mim, o maior suplício seria estar só no paraíso". O que seria pior, nunca escapar ao olhar do outro, ou jamais poder nele espelhar-se? Ora, uma sociedade que faz do bem-estar seu Deus, do consumo seu templo e do corpo seu livro santo, ao invés de criar um clima de benevolência e tolerância para com os outros, cria a exasperação dos conflitos inter-humanos, os tormentos de inveja, o desprazer com o sucesso e a felicidade dos outros, exacerbando os sentimentos de ódio e inveja, a rivalidade e as competições desonestas entre iguais e gerando mais frustração e decepção que propriamente bem-estar, dois grandes obstáculos à felicidade, sempre postergada, por mais numerosas que sejam as satisfações vividas e as emoções sentidas. Porque a corrida desenfreada em busca da felicidade privada (a escalada do carpe diem), ao invés de trazer a felicidade, apenas exacerba o culto da auto-estima, do bem-estar, dos lazeres e divertimentos.

Um outro aspeto que gostaria de salientar: vivendo numa sociedade de hiperconsumo, sociedade flexível e sem fronteiras ou limites (sociedade fluida ou líquida - Z.Bauman), o individuo parece ter muita dificuldade para experimentar verdadeiros sentimentos, posto que a flexibilidade e a fluidez do sistema econômico impõem a imediatez e a instantaneidade das relações, pondo em questão todo engajamento a longo prazo. $\mathrm{O}$ indivíduo contemporâneo tem um tremenda dificuldade de viver valores a longo prazo (fidelidade, engajamento, lealdade) numa sociedade que só se interessa pelo imediato e na qual as exigências de flexibilidade generalizada impedem a manutenção de relações duráveis e de experimentar um sentimento de continuidade de si. Por outro lado, a família perdeu o privilégio de constituir o cadinho da educação e da formação cultural dos indivíduos. Num mundo onde desaparece cada vez mais tudo o que é contínuo, durável e sólido, a educação familiar enfatiza a capacidade de adaptação e mudança, formando personalidades "desengajadas" e flexíveis, capazes de construir e reconstruir identidades múltiplas. O que nos leva a refletirmos sobre a atualidade da afirmação de Aristóteles: “O amigo é um outro-eu”. O homem nunca deveria estar só. Porque só está só quando só se basta. E ninguém se basta. Quando estou só, fico necessariamente cego em relação à minha pessoa. Ao abrir- 
me ao amigo e com ele dialogar, dou-me os meios de me compreender, lá onde a introspecção, paradoxalmente, fracassa. Assim, o verdadeiro amigo é uma espécie de alter-ego ou "outro-eu". A amizade possui uma dignidade totalmente única entre o inventário das relações com o outro: amo meu amigo tanto quanto amo a mim mesmo. Montaigne costumava dizer: "Há tanta diferença entre nós e nós mesmos quanto entre nós e o outro". Donde a amizade ser "a união de duas pessoas ligadas por um amor e um respeito iguais e recíprocos" (Kant).

Quanto aos encontros duráveis (de amizade, no sentido supra-mencionado), foram substituídos por encontros breves, ordinários, efêmeros e intermutáveis, encontros onde as relações começam tão depressa quanto terminam. Claro que os elos sociais são mais numerosos que antes, mais fáceis de serem estabelecidos, mas são muito mais frágeis. O transtorno do mercado amoroso pela explosão dos sites de encontro na Internet constitui uma boa ilustração. Numa de suas obras, $O$ amor líquido, Zigmund Bauman nos mostrou a tual "fragilidade dos vínculos entre os homens". E não se trata apenas de uma questão da relação amorosa, mas da relação pura e simples com os outros. Claro que o amor ocupa um lugar preponderante. O fenômeno dos encontros na Internet constitui uma das expressões mais emblemáticas das relações líquidas contemporâneas. Muito embora elas sejam ao mesmo tempo tão intensas e facilmente revogáveis. Ademais, esses encontros são realizados num contexto de grande segurança: "A conclusão a pedido - instantânea, sem crise, sem revelar perdas elou ganhos constitui a maior vantagem dos ciberencontros. Uma redução dos riscos é tudo o que resta da escolha racional num mundo de ocasiões flúidas e valores mutante que, contrariamente à delicada negociação dos engajamentos naturais, satisfazem quase perfeitamente esses novos critérios de escolhas racionais". Porque, afinal, sempre podemos apoiar sobre a tecla "deletar". Nada mais fácil do que não responder a um email!

O fato é que assistimos hoje a uma efemerização das relações com o outro. Ora, privado do tempo e da duração que exigem os sentimentos, será que o indivíduo de hoje ainda pode experimentar outra coisa distinta de sensações, por mais fortes que possam parecer? Será que o tal "sentir" não está se reduzindo à simples "sensação", a que é experimentada no fluxo ininterrupto dos acontecimentos e das mudanças nas quais parece encontrar-se afogado? Com o enfraquecimento de muitas proteções sociais ligadas ao trabalho (nas últimas décadas) e com a precariedade geral que isso gerou, tudo indica que cada vez mais o indivíduo tem necessidade de alguns suportes sociais 
para conseguir conduzir-se de forma autônoma e instaurar um compromisso entre mobilidade e segurança. Há todo um "mudancismo" ou "troquismo" que, em sua ânsia de expulsar a insegurança, propõe uma nova espécie de contratualização das relações sexuais. Para além das relações íntimas, um instrumento como o celular cada vez mais está fazendo dessa busca frenética de encontro com os outros um dos meios mais privilegiados para se tentar fugir da insegurança e da solidão. Tudo se passa como se os indivíduos, ao abrigo de uma tela de chamadas e mensagens, fossem mais ou menos invulneráveis! Como se fosse o único ponto de estabilidade num universo de objetos mutantes! Como se as conexões fossem rochedos no meio de areias movediças! Donde o paradoxo dessas novas comunicações virtuais: ao mesmo tempo que o celular permite aos que permanecem distantes entrarem em contato, permite aos que entram em contato permanecerem distantes. Donde a constatação lapidar do sociólogo Bauman: $O$ mundo parece hoje conspirar contra a confiança". Porque é o conjunto das relações sociais que parece marcado "de uma fluidez, de uma fragilidade e de uma fugacidade internas sem precedentes". Este é justamente o caso, por exemplo, no domínio do trabalhão, com sua famosa "flexibilização".

Com a ampliação das liberdades individuais, com o enfraquecimento das hierarquias e a suavização das normas, criaram-se as condições, não só para que fosse posto o problema da autonomia individual e do juízo pessoal, mas para que os valores sociais e religiosos recuassem diante do princípio do prazer. Neste domínio, as decisões se tornam mais difíceis de ser tomadas, pois desaparecem os critérios externos de arbitragem. Há uma interiorização das normas. A felicidade é vista como uma satisfação cuja fonte é interior. A moral passa a ser da competência de cada um. O drama do indivíduo contemporâneo não é tanto a incerteza ou o excesso de liberdade, mas certa "desfiliação", consequência de uma ruptura dos elos que o uniam à sociedade através do trabalho, da família e das instituições. O indivíduo não padece tanto de culpabilidade, mas de vergonha deste sentimento proporcionado pelo olhar dos outros. Por isso, poderia até preferir, à lucidez de um Pascal que, ao declarar que "o silêncio eterno desses espaços infinitos me apavora" e que o homem que negligencia Deus se expõe à angústia de uma extrema solidão, o prudente conselho de Voltaire para "cultivar seu jardim": sua felicidade crescerá num mundo reduzido às dimensões humanas e à medida de suas esperanças.

Nas últimas décadas, assistindo, não só a uma crescente permissividade sexual, a um constante questionamento da família e dos elos contratuais do casamento e da RPI Revista de Pesquisa Interdisciplinar, Cajazeiras, v. 1, n. 1, 91-110, jan/jul. de 2017. 
filiação, mas ao desenvolvimento dos principais direitos individuais, o indivíduo sofre muito com a "desinstitucionalização" da família, pois ela dá lugar a formas cada vez mais "eletivas" de vida privada. Não sabe mais como viver num mundo onde as relações são cada vez mais escolhidas. Claro que algumas impositivas persistem, como a de escolher seus pais. Sobre este aspeto, é incontestável o aparecimento de novas inquietações. Quanto à questão do recuo dos valores, não são raros os que vão procurar dados significativos na religião, notadamente em suas formas mais sectárias, messiânicas, evangélicas ou orientais.O que é compreensível. Porque sabemos que, de essência normativa, há milênios a religião tem apaziguado e tranqüilizado, por seus relatos, ritos e cultos diversos, as angústias da humanidade diante das forças da natureza que ameaçam esmagá-la; e contribuído, por suas cerimônias, para estabelecer e reforçar os elos sociais (religare) unindo os seres humanos no interior da comunidade. Eis sua função política.

A mais clara característica da busca de sentido do indivíduo contemporâneo é seu imperioso repatriamento no aqui e agora, no famoso carpe diem: colha o dia, aproveite o momento. Esta expressão do poeta Horácio (65-8 a.C) não constitui o resumo econômico do epicurismo, um convite a aproveitarmos cegamente o momento presente sem nos preocuparmos com qualquer outra coisa. Não temos o direito de confundir um hedonismo grosseiro com o autêntico epicurismo, Horácio preconiza uma busca racional do prazer. Claro que a vida é breve, e a morte certa. Mas isto não nos permite nos lançarmos no turbilhão dos prazeres desenfreados! Jamais o grande mestre grego pretendeu nos convidar a multiplicarmos sem freio nossos gozos efêmeros. Pelo contrário, convidou-nos a evitar os desejos suscetíveis de nos tornar instáveis ou infelizes, notadamente o desejo de imortalidade, tão lancinante quanto impossível de satisfazer. Eis por que precisamos construir, no presente, uma higiene de vida perene permitindo-nos aceder ao equilíbrio do corpo e à serenidade da alma. Esta sabedoria se encontra muito distante da vida de deboche que por vezes emprestamos aos epicurianos: a verdadeira felicidade implica saborearmos o instante presente, sem dúvida, mas no contexto de uma disciplina de vida exigente, tendo por mestres a prudência e a moderação.

Donde a pertinência das palavras de Pascal: “Jamais vivemos, mas sempre esperamos viver; sempre dispostos a sermos felizes, é inevitável que jamais o sejamos". Claro que a felicidade é o horizonte de nossa existência. Nossas escolhas balizam a edificação desse ideal ao qual aspiramos com tanta avidez. Mas, paradoxalmente, será 
nossa busca frenética da felicidade que torna impossível seu gozo? A preocupação obsessiva com a felicidade gera uma existência inquieta, dilacerada entre a nostalgia de um passado alegre e a impaciência de uma felicidade ainda por vir. Quando toda nossa atividade é investida na busca frenética de um bem-estar em vista do qual dispendemos enormes esforços, a felicidade simplesmente é postergada. Assim, "esperamos viver" mais do que aproveitamos dos momentos felizes que nos são ofertados. Mas não seria uma aposta arriscada, pois não temos garantia de aceder a essa felicidade tão desejada? No fundo, deixamos escapar a única coisa que nos pertence: o presente, pois fazemos dele um simples meio em vista de um fim apenas provável: o "futuro". Daí o veredicto de Pascal nos lembrar uma verdade essencial: nossa relação com o tempo hipoteca nossas possibilidades de felicidade. Tanto o avaro, que se priva de tudo para poupar, quanto o ambicioso, que desdenha do presente em nome de uma glória futura, reservamse para um depois que vai chegar. A lição? É um mau cálculo morrermos demasiado preocupados, postergando sempre para amanhã nossa felicidade real.

Aliás, o que mais caracteriza nosso tempo atual não é tanto a cultura neodionisíaca repousando apenas na preocupação com o presente e com os desejos de gozo aqui e agora, mas a inquietude face a um futuro povoado de riscos e incertezas, a um futuro que se tornou tremendamente precário e incerto. Os filósofos têm toda razão de dizer, reconhece Kierkegaard, que só compreendemos a vida voltando-nos para o passado. "Mas se esqueceram de outra proposição não menos verdadeira: a vida só pode ser vivida projetando-se para o futuro". Prever o futuro não significa sucumbir no fatalismo. Mas tomar o futuro previsto por guia de nossa ação presente. O que declina hoje não é tanto a importância do futuro, mas o ethos posmoderno do hic et nunc. O que pode ser ilustrado pelas novas atitudes em relação à saúde. Quando a normalização médica praticamente invade todos os territórios do campo social, a saúde se torna uma preocupação onipresente para um número crescente de indivíduos. O que levou o ideal hedonista a ser suplantado pela ideologia da saúde e da longevidade a todo preço. Em nome desse ideal, o indivíduo é capaz de renunciar a muitas de suas satisfações imediatas e de corrigir ou reorientar seus comportamentos. Mas sem se esquecer de que seu sentimento, em relação ao futuro da humanidade, constitui uma mescla de medo e de culpabilidade: “medo, porque a previsão nos mostra justamente terríveis realidades; culpabilidade, porque estamos conscientes de nosso próprio papel em seu desencadeamento" (H. Jonas). 
Donde o fato novo: a moral do instante está cedendo o lugar ao culto da saúde, à ideologia da prevenção, da vigilância sanitária e da medicalização crescente da vida humana. O indivíduo cada vez mais tem necessidade de prever, antecipar, projetar e prevenir, comer orgânico, perder peso, vigiar as taxas de colesterol, não fumar, praticar esportes: sua obsessão narcísica ou egolátrica com a saúde e a longevidade anda junto com a prioridade do depois sobre o imediato. Obcecado pelo consumo, imerso numa torrente de fúteis solicitações e frívolas emoções, muito preocupado com "viagens", com o insólito, com transgressões e músicas embriagantes, seu objetivo fundamental, nos diz Lipovetsky,

[...]é o de quebrar os limites de seu Ego livrando-se de todo centro e de toda objetividade num paroxismo de sensações e pulsações do desejo. O grande desejo de Dionísio é o de evadirse de si, repudiar o Ego mergulhando no informe e no caos e afundando-se no oceano das sensações ilimitadas. Libertar-se da prisão do Ego, livrar-se das dores da individuação, fazer explodir o principium individuationis: eis o sentido profundo do homem dionisíaco (...) em busca do hedonismo e do sensualismo dos costumes. Numa cultura entregue aos prazeres sensoriais e aos desejos de gozo aqui e agora, é toda a vida social e individual que se deixa envolver por um halo 'orgiástico"' (Le bonheur paradoxal, Gallimard, 2006, p. 190).

Não é a vida eterna ou a salvação de sua alma que o indivíduo atual busca conquistar ou garantir, mas simplesmente um melhor-estar de sua vida privada no imediato do aqui e agora vivido na perspectiva de uma vida longa e sadia. Lança mão de todas as suas energias e de sua inteligência para conquistar um bem-estar material como o substituto perfeito de uma inalcançável felicidade espiritual ou de sua alma. Não se dá conta de que o acúmulo de bens materiais, ao invés de preenchê-lo e torná-lo feliz, o esvazia e o torna entediado e deprimido, comprometendo e minando sua densidade ética, suas antigas solidariedades sendo substituídas por anônimas e falsas solidariedades burocráticas. Nas múltiplas formas que revestem as expressões da religião que adota, as que mais se destacam são as que lhe parecem trazer uma melhora aqui e agora, obter alguns sucessos na vida profissional, ser socialmente aceito e reconhecido, sem grandes preocupações com o além da morte. O que mais lhe interessa é a busca de uma eficácia em estreita correspondência com os imperativos da construção de si, no contexto da sociedade de consumo e concorrencial. A concorrência 
dos Egos faz um grande estrago na convivência solidária. O que sobra são as pequenas felicidades privadas, realizadas no nível das liberdades de nossas sociedades. Para alguns, a carreira e o sucesso; para outros, o prazer dos encontros e a alegria das emoções; para todos, o consumo, o esporte, o divertimento e as viagens.

Podemos chamar essa busca de "transcendência de si": o que a caracteriza é o fato de ser feita em nome de si e de a fonte de sentido ser ele próprio. São muito estreitas as fronteiras entre essa busca de si e a de Deus, pois essa transcendência de si freqüentemente flerta com a busca, não de um Deus transcendente ou pessoal, mas de um Deus que o indivíduo acredita trazer dentro de si. No fundo, trata-se de uma busca de si, de um Deus fazendo parte de si, nada tendo de frio, inacessível ou longínquo. O indivíduo, diante do absurdo da condição humana, mas procurando descobrir um sentido para sua vida, parece só encontrá-lo no silêncio insondável das coisas, a começar pelo silêncio de sua própria morte. A situação é insolúvel, pois busca no mundo uma razão que está em si mesmo. Assim, não conseguindo inventar-se um futuro ilusório e se recusando a criar-se um "além religioso" e não conseguindo escapar de sua existência, precisa "imaginar Sísifo feliz" (Camus). Enquanto espera, apega-se ferrenhamente a seu instinto vital de conservação. O cuidado com seu corpo o leva diretamente à questão de si. Sem ser mais comandado por uma ordem cósmica identificável, deixa-se levar pelo apelo a fundir-se num misterioso Todo mais ou menos energético ou cósmico. E retorna com força seu velho instinto de evasão metafísica. Torna-se comum o recurso às drogas, aos transes, aos êxtases e ao exílio. Fugir e refugiar-se em si se tornam dois modos preferidos de sua relação com a realidade.

De um mondo geral, o Deus do indivíduo egolatra não é mais o "Deus dos filósofos e dos sábios", o Deus-Fundamento, o Deus-Ato puro, o Deus-Supremo relojoeiro e arquiteto do racionalismo das Luzes. Muito menos, um Deus pessoal. Tratase de uma divindade que se encontra muito além de nossas representações e de nossos conceitos. Na prática, confunde-se com uma espécie de Absoluto mistérico, energético ou cósmico manifestando-se nas mais extravagantes experiências individuais do "conhecimento" místico, esotérico, transcendental, oculto ou religioso: no autoconhecimento exaltando certo maravilhosismo e certo experimentalismo. Ao perder a fé nos discursos teóricos, esse indivíduo se entrega freneticamente a consumir o "espiritual”, o "energético" ou o "mistérico" sem jamais se sentir saciado. De um lado, assistimos ao recuo das práticas, ao enfraquecimento dos magistérios e à marginalização das Igrejas tradicionais; do outro, à multiplicação desordenada das crenças, muitas delas 
consumidas como "produtos" num espírito de adesões sectárias a fim de saciar a fome de espiritualidade. Tudo se passa como se só tivesse valor o princípio de moral socrático "conhece-te a ti mesmo", como se ele fosse um convite à introspecção ou ao “desenvolvimento pessoal”. Só que esse princípio nada tinha de um apelo psicológico ao egocentrismo ou ao narcisismo. O conhecimento de si era a condição fundamental da sabedoria, da liberdade e da virtude. Só o instruído sobre si conseguia adquirir o que lhe faltava e evitar o que estava acima de suas capacidades. A observação crítica de seu ser o tornava capaz de moderar seus prazeres e distanciar-se do mal. Só não busca evitar o mal quem dele espera tirar proveito. Ninguém o deseja, pois é portador de infelicidade.

Por viverem mais ou menos afogados no presente, os indivíduos de hoje são ao mesmo tempo mais informados e mais desestruturados, mais adultos e mais instáveis, menos ideologizados e mais tributários das modas, mais abertos e mais influenciáveis, mais críticos e mais superficiais, mais céticos e menos profundos. Não vivem mais a desagregação do mundo da tradição sob o regime da emancipação, mas sob o da crispação. É o medo que prevalece e domina face a um futuro incerto, a uma lógica da globalização se exercendo independentemente deles. Qual um Narciso, o indivíduo egolatra está mergulhado na inquietude. Nele, o medo se impõe ao gozo. E a angústia se impõe à liberação. Sua obsessão de si se manifesta menos na febre do gozo que no medo da doença e da idade, na medicação da vida, numa palavra, na depressão. Narciso está aterrorizado pela vida cotidiana: tudo o apavora. Neste contexto, cai facilmente na tentação do consumismo frívolo de sensações, de aceitar uma religiosidade à la carte, o "religioso" se convertendo num esteticismo gustativo das realidades mistéricas, ocultas ou esotéricas, implicando a aceitação de certa idolatria ou de certo panteísmo gnosticista. E sua busca frenética por uma felicidade ferida e angustiada passa a ser preenchida de insaciáveis prazeres privados, quase sempre por meio de estimulantes artificiais. Se Narciso se inquieta, é porque nenhum discurso teórico parece satisfazerlhe e dar-lhe uma garantia. Donde entregar-se ao consumo mais ou menos frenético do espiritual, passando a substituir as ideologias com pretensões teológicas, as convicções escatológicas e a crença numa verdade da história pela frivolidade das emoções e pelo fascínio das espiritualidades mais ou menos esotéricas e orientais.

Ora, num universo onde o consumo de bens se apresenta como uma espécie de "sonho acordado", o indivíduo praticamente se deixa dominar pelo mundo da sedução e dinamizar sua vida pela lógica da moda. Tudo se passa como se devesse organizar seu presente pela lógica da novidade (não do novo, que lhe dá medo, pois o põe em questão) 
e pela tentação compulsiva das compras suscetíveis de fornecer passageiros prazeres, certo bem-estar e algumas sensações de alegria ou euforia, inclusive, de terapia. Muitos são os que utilizam os shoping-centers para realizar sucessivas "terapias breves" Amplia-se o gosto das novidades, da promoção do fútil e do frívolo, do culto do desabrochamento pessoal e da auto-estima, em suma, da ideologia individualista hedonista que, depois de experimentar tristes desilusões, angústias e medos, desemboca no niilismo, neste fenômeno espiritual ligado, não só à morte de Deus e dos valores morais, mas à idéia de que o futuro é sem objetivo. A comercialização dos modos da vida individual e social é rigorosamente organizada em função da lógica do consumo. Nem mesmo o domínio da espiritualidade escapa ao princípio do self-service, à busca de emoções e prazeres e ao cálculo dos benefícios individuais (levar vantagem): privados do sentimento de uma verdadeira Transcendência, os indivíduos, vivendo a angustia do vazio dos valores, possuem cada vez menos convicções religiosas e cada vez mais opiniões flutuantes, tomando por "verdadeiro" o que "acreditam" (no nível da opinião) ou "sentem"(no nível da sensação) ser verdadeiro. Adotam um relativismo epistemológico e ético como se a verdade pudesse ser refutada e as regras morais variassem a cada instante! Aristóteles já dizia que a verdade não admite contestação, porque, para negá-la, seria preciso utilizá-la na própria tentativa de negá-la.

Vivendo num mundo e num momento em que a comercialização dos modos de vida não encontra mais resistências estruturais, culturais ou ideológicas, e em que as esferas da vida individual e social passaram a ser organizadas em função da lógica do consumo, não é de se estranhar que a prevalência crescente do princípio do self-service, da busca de emoções e prazeres, do cálculo utilitarista e da superficialidade dos vínculos venha contaminar todo o conjunto do corpo social e, até mesmo, a espiritualidade individual. Também a religião se torna um "produto" de consumo, seus "fiéis" abandonando o ascetismo em proveito do hedonismo e do gosto pelas festas: as exigências de ascetismo, contrição e reconhecimento são substituídas por vivências $e$ emoções, por celebrações festivo-musicais mais aptas a exorcizar a solidão e o tédio e a trazer certa paz interior ou conforto espiritual aos caçadores de autoconhecimento e aos famintos de autoajuda do que exprimir as convicções profundas de uma fé vivida na lucidez e na partilha da caridade, como se o amor-posse ou de aquisição pudesse substituir o de doação: "ama, e faze o que queres" (santo Agostinho). Porque não acredito que o homem busque sempre seu próprio benefício, como se seu desejo estivesse voltado apenas para a posse de coisas com muita paixão. Não podemos nos 
esquecer da advertência do sábio Sócrates: a felicidade não é ter coisas, mas um modo de ser: depende da maneira como o homem com elas se relaciona "Se queres ser feliz, cuida de tua alma: sejas bom, honesto e justo; o injusto é mau e infeliz"(Górgias, 470C).

Por isso, numa época dominada por neoliberalismo conservador como a nossa, uma das condições para sermos felizes é a de nos opormos a ele, dele termos uma visão crítica, não termos medo de organizar nossa esperança e de resgatar as utopias, porque é espiritualmente anti-higiênica e faz mal à saúde espiritual uma ideologia que, transformando o Progresso em ídolo, mercantiliza tudo e exige do cidadão a renúncia à liberdade. Donde precisarmos abandonar essa monotonia espiritual e fazer da Razão uma realidade incompleta jamais devendo repousar na tradição. Porque acredito que as Luzes, não só por seus méritos, mas também por suas insuficiências, continuam a nos ajudar a identificar a possibilidade de uma racionalidade mais adequada aos desafios dos tempos presentes. É desta maneira que a Razão se torna jovem e incisiva, levandonos a aceitar e viver o princípio segundo o qual "nada é fixo para aquele que alternadamente pensa e sonha": precisamos de pensadores que saibam sonhar e de sonhadores que saibam pensar. Porque nosso conhecimento deve aparecer como a reforma de uma ilusão e uma retificação continuada. Claro que navegar é preciso. E viver, muito mais preciso ainda. Mas se não navegarmos com uma bússola na mão e um sonho na cabeça, ficaremos condenados à rotina do sexo, da droga e do credit card. E o ideal proposto à juventude (viciada em divertimento) passa a ser apresentado como o mais compulsivo consumismo perfumado de hedonismo.

Diante da atual patologia mental de milhões e milhões de pessoas, vivendo totalmente sob o domínio do medo, da tristeza e da depressão, qual o melhor remédio possível para que cada um de nós posa atingir um grau razoável de felicidade? Não teria razão o filósofo Paul Ricoeur quando nos diz que é justamente a "excentricidade utópica que constitui o remédio pra a patologia do pensamento ideológico, que se encontra precisamente cego e estreito em razão de sua incapacidade de conhecer um lugar nenhum"? Ele fala de utopia, No entanto, nossas sociedades só estão preocupadas com cuidados psicológicos! Nunca tivemos tantos modos científicos de intervenção visando nosso bem-estar, nosso equilíbrio mental, nossa harmonia psicocorporal proporcionando-nos o máximo de prazer e o mínimo de dor possíveis! Exceto, talvez, no Melhor dos mundos. Cada vez mais os indivíduos estão se tornando "psicômanos", buscando meio desesperadamente as melhores drogas, as mais eficazes e 
rápidas psicoterapias como remédios para seus males. A este respeito, vale lembrar a sabedoria dos Gregos, alertando-nos contra a ambigüidade de toda terapêutica: o termo pharmacon designa remédio e veneno. O mérito desse duplo sentido? Primeiramente, alertar-nos contra as receitas milagrosas e os riscos das terapias não motivadas por uma necessidade vital. Em seguida, levar-nos a desconfiar da exagerada confiança depositada no novo ópio do povo constituído pelas diversas técnicas psicológicas ou "espirituais" visando melhorar e manter em bom estado nossa vida afetiva, intelectual e espiritual. Este progressivo e exagerado consumo de terapias pode fazer mal à nossa saúde mental.

Ora, com o desmoronamento das ideologias de esquerda, com o triunfo da sociedade de consumo, com a crise das significações imaginárias da sociedade moderna, tudo isso manifesta uma crise do sentido, uma crise de perda ou ausência de sentido, culminando numa espécie de niilismo anunciando a evanescência praticamente completa dos valores, o único valor subsistente sendo o dinheiro. $\mathrm{O}$ indivíduo egolatra se esquece de que o esquecimento de uma felicidade no nível espiritual e sua substituição por uma felicidade reduzida à fruição dos bens de consumo possui profundas raízes niilistas. O ideal sublime da vida social? "Tentar ganhar dinheiro". Neste tipo de sociedade, em que se torna o indivíduo livre, soberano e autárquico senão numa marionete realizando espasmodicamente os gestos que lhe impõe o campo sóciohistórico: ganhar dinheiro, consumir, se divertir e "gozar" (quando possível, com ajuda farmacológica)? Suposto "livre" para conferir à sua vida o sentido que "quer", na maioria dos casos só se confere o "sentido" imposto pela sociedade: consumir cada vez mais e levar uma vida desprovida de qualquer sentido, pois só consegue vencer a si mesmo do modo como o sistema quer, isto é, anulando sua prórpria identidade, anulando-o como homem livre e ficando condenado a "amar o Big Brother" (G.Orwell). O resultado? Sua "autonomia" se torna heteronomia. E sua "autenticidade", conformismo.

Donde estarmos assistindo à instalação de uma insidiosa e intimidante violência fazendo impor esse generalizado conformismo. Porque uma sociedade estruturada com base em formas de um produtivismo e de um consumismo tecnocientíficos, tendo por finalidade o crescimento econômico em vista de um Progresso apenas material, cobra um preço bastante elevado aos cidadãos: a renúncia à sua liberdade, pois acredita ter condições de satisfazer a todas as suas necessidades. Os projetos de autonomia individual sofrem um eclipse quase total. Em grande parte, causado pela onda crescente 
de privatização, despolitização e individualismo exacerbado. Um grave sintoma concomitante: a total atrofia da imaginação política e o empobrecimento intelectual de nossas lideranças. Cada vez mais a liberdade funciona como um simples complemento instrumental do dispositivo maximizador dos "gozos" individuais privados, o único valor exaltado sendo o dinheiro conferindo poder e certa notoriedade midiática. A sociedade atual adquiriu a tremenda capacidade de abafar toda verdadeira divergência, seja silenciando-a, seja convertendo-a num fenômeno comercializado como os outros. As vozes discordantes e dissidentes são mercantilizadas e manipuladas. Donde a pertinência de continuarmos pensando (sonho?) uma sociedade onde:

- os valores econômicos não mais se imponham como centrais e únicos e o absolutismo tecnológico, que só aparece como uma fonte de conhecimento, de bem-estar e de progresso materiais, não continue impondo um novo monoteísmo: o do mercado, incapaz de compreender o que é a vida

- a cultura não seja identificada com o mero entretenimento (com o que se vende), mas com tudo o que ultrapassa o simples funcional e o instrumental, humanizando nosso espírito e nossa consciência. Ela é tudo o que fornece ao indivíduo razões de viver e esperar, bem como os meios de agir a fim de aumentar a beleza e a sabedoria do mundo

- o crescimento máximo seja considerado um meio, não o fim das ações humanas. E o intelectual possa afirmar-se e definir-se por fazer uso apenas da lógica da argumentação, da refutação e do diálogo, por defender sua liberdade em relação a todos os poderes, pela crítica permanente que faz das idéias recebidas e pela demolição das alternativas simplistas. Sua "via é escarpada", mas "acessível e possível" (Espinoza). Mas como poderia sê-lo "se a salvação estivesse tão próxima e pudéssemos alcançá-la sem trabalho? Tudo o que é precioso é difícil e raro". Por isso, respondendo a Pascal, para quem "toda a filosofia não merece uma hora de esforço", diria: o amor da sabedoria vale uma eternidade de alegria. 